\title{
Seroprevalence of Hepatitis B Infection among Health Care Workers and the Importance of Anti HBs Testing among the Health Care Workers
}

\author{
Reshmi Gopalakrishnan $^{1^{*}}$ and Srinath Ramamurthy ${ }^{2}$ \\ ${ }^{1}$ Department of Microbiology, Malabar Medical College Hospital and Research Centre, \\ Modakallur, Calicut, Kerala, India \\ ${ }^{2}$ Surveillance Medical Officer, Calicut, World Health Organisation, Kerala, India \\ *Corresponding author
}

\section{A B S T R A C T}

\begin{tabular}{|c|c|}
\hline Keywords & $\begin{array}{l}\text { Healthcare workers are at a high risk of occupational exposure to many blood-borne } \\
\text { diseases including HIV. Hepatitis B. Hepatitis } \mathrm{C} \text { viral infections. Of these only }\end{array}$ \\
\hline $\begin{array}{l}\text { Health care } \\
\text { workers, Hepatitis } \\
\text { B virus, Anti HBs } \\
\text { titre, Hepatitis B } \\
\text { vaccination. }\end{array}$ & $\begin{array}{l}\text { Hepatitis B infection is vaccine preventable. This study was conducted to determine } \\
\text { the seroprevalence of Hepatitis B virus infection and to determine the anti HBs } \\
\text { antibody titres among the health care workers. A descriptive cross sectional study was } \\
\text { conducted among } 52 \text { health care workers of a clinical laboratory. HBsAg detection }\end{array}$ \\
\hline Artic & \\
\hline $\begin{array}{l}\text { Accepted: } \\
\text { 21 September } 2017 \\
\text { Available Online: } \\
10 \text { October } 2017\end{array}$ & $\begin{array}{l}\text { doses of vaccines and they had attained protective antibody levels of }>10 \mathrm{mIU} / \mathrm{ml} \text {. The } \\
\text { remaining participants were either not immune or had low antibody levels of }<10 \\
\mathrm{mIU} / \mathrm{ml} \text {. A significant number of health care workers are unvaccinated suggesting the } \\
\text { need for proactive implementation of } \mathrm{HBV} \text { vaccination programme. }\end{array}$ \\
\hline
\end{tabular}

\section{Introduction}

Hepatitis B infection is a serious global public health problem. More than two million people have been infected with Hepatitis B Virus (HBV) and approximately 400 million people are carriers of the virus. [1]. According to the World health Organisation (WHO) approximately 240 million people are chronically infected with HBV infection and more than 7,80,000 die every year due to its consequences[2]. India is considered to have intermediate level of HBV endemicity with a prevelance rate of $2-8 \%[3,4]$. The number of HBsAg carriers in India has been estimated to be over 50 million.
Health care workers (HCWs) are at an increased risk of occupational exposure to HBV and the incidence is 2- 4 times higher than general population. Despite potential risks, awareness and vaccine compliance is poor among the HCWS [5]. Throughout the world, millions of healthcare professionals work in health institutions and it is estimated that 600,000 to 800,000 cut and puncture injuries occur among them per year, of which approximately 50\% are not registered [6]. The risk of contracting $\mathrm{HBV}$ by health care workers (HCWs) is four-times greater than that of general adult population [7]. The 
highest rates are seen among dentists, physicians, laboratory workers, dialysis workers, cleaning service employees, and nurses [8]. Blood contains the highest HBV titers of all body fluids and is the most important vehicle of transmission in the health care setting. Avoiding occupational blood exposure is the primary preventive means for the transmission of HBV. Immunization and after exposure management are integral components of a complete infection control program for this group [9]. Because of the high risk of HBV infection among HCWs, routine pre-exposure vaccination of HCWs against Hepatitis B and the use of universal precautions to prevent exposure to blood and potentially infectious body fluids have been recommended in many countries. [10].

The risk of HBV in an unvaccinated person after a single episode of needle prick injury ranges from $6-30 \%$ [11] and even $0.00001 \mathrm{ml}$ of blood can transmit HBV [12] Vaccination is an easy and cost effective measure to prevent disease and infection, since it eliminates persistent HBV infection, diminishes the pool of carrier state [13]. A complete standard vaccination consists of 3 doses, administered as 0,1 , and 6 month schedule. This induces protective antibody concentrations $>90 \%$ healthy adults $[14,15]$.

Reports from India indicate that only 16-60\% of HCWs have received complete HBV immunization. Paramedics have a higher risk of $\mathrm{HBV} / \mathrm{HCV}$ transmission and receive $\mathrm{HBV}$ vaccination less often than doctors [16, 17]. The practice of universal precautions, such as safe needle disposal, wearing gloves during phlebotomy and using goggles is suboptimal among HCWs in developing countries [18, 19].

In the present study we evaluated the prevalence of HBV infection and anti- HBs titre among the health care workers of our clinical laboratory. We also analyzed the data regarding the knowledge of hepatitis $B$ immunization among the HCWs.

\section{Materials and Methods}

A descriptive cross sectional study was conducted among 52 health care workers of a clinical laboratory for a period of 1 year. They belonged to the age group of $20-60$ years. Participants consisted of doctors, laboratory technicians and laboratory attendants. A written consent was obtained from each participant. All the participants were asked to complete a standard questionnaire consisting of their age, gender, job description, educational status, alcohol history.

Details such as status of HBV vaccination, exposure to blood and/or blood products, history of blood transfusion were also recorded. Volunteers who gave past history of chronic liver disease, patients with documented immune suppression or on prolonged steroid therapy or anti-tubercular treatment and pregnant women were excluded from the study.

3-5ml of blood sample was drawn from each participant under strict aseptic precautions in a plain vacutainer. Blood was allowed to clot and serum was separated and stored at -20 degree $\mathrm{C}$ until further testing.

\section{Assessment of Hepatitis B infection}

HbsAg testing was done by enzyme-linked immunosorbent assay (ELISA) using a commercial kit (J. Mithra) according to the manufacturer's protocol.

\section{Assessment of anti HBs titres}

Antibody titres were done by VIDAS using commercially available ELFA kits (Rosche Diagnostics). Anti-HBs titre of $>10 \mathrm{mIU} / \mathrm{ml}$ were considered protective. 
All vaccinated HCWS were divided into 3 groups on the basis of duration completion of their full schedule of vaccination. Those who were vaccinated within last 5 years belonged to group A, those who were vaccinated between $5-10$ years belonged to group B and those who were vaccinated before 10 years belonged to group $\mathrm{C}$.

\section{Statistical analysis}

Statistical analysis was done using Fishers exact test.

\section{Results and Discussion}

A total of 52 participants were included in the study. Of these 11 were males $(21.15 \%)$ and 41 were females $(78.85 \%)$. 3 of our participants were doctors $(5.77 \%), 45$ were laboratory technicians $(86.54 \%)$ and 4 were laboratory attendants (7.69\%). 18 participants (34.62\%) were completely vaccinated for hepatitis B with three doses of the vaccine. 4 participants gave history of incomplete vaccination $(7.69 \%)$. These 4 participants had missed their $3^{\text {rd }}$ dose of vaccination. 30 participants $(5.69 \%)$ were not vaccinated at all (Table 1).

It was observed that of the total 18 participants who were completely vaccinated, the 5 participants $(27.78 \%)$ who had received complete vaccination $<5$ years ago and the 10 participants (55.56\%) who had received complete vaccination 5-10 years ago before the study, had protective anti HBs titre $(>10 \mathrm{mIU} / \mathrm{ml})$. These participants had an anti HBs titre of $>100 \mathrm{mIU} / \mathrm{ml}$. Whereas the 3 participants $(16.67 \%)$ who had received the complete course of vaccination more than 10 years ago, the anti HBs titre ranged from $10-$ $100 \mathrm{mIU} / \mathrm{ml}$.

None of our participants were acutely infected at the time of the study. None of the participants were immune due to natural infection (recent or remote). All the participants were HBsAg negative at the time of the study.

All unvaccinated HCWs were prescribed Hepatitis B vaccine and were counselled to get checked for serological response after 1 month of full course of vaccination. All the HCWs whose anti HBs titre was $<10 \mathrm{mIU} / \mathrm{ml}$ were also asked to take a complete course of Hepatitis B vaccination. The 4 participants who were incompletely vaccinated did not have adequate antibody levels and hence were asked to take a complete course of vaccination.

This study was conducted with the aim of creating awareness among the HCWs about the risk of HBV transmission through contact with blood and body fluids and also to raise the vaccine compliance among the HCWs.

Vaccination is an important step in preventing Hepatitis B virus infection among HCWs. Estimates of Hepatitis B vaccine coverage are needed to interpret the proportion susceptible to HBV infection. Unfortunately the practice of vaccination is not yet well accepted.

According to WHO estimates, Hepatitis B vaccination coverage among health-care workers varies from $18 \%$ being lowest in Africa to highest $77 \%$ in Australia and New Zealand [20]. Surprisingly even in some of the developed countries like Sweden, only $40 \%$ HCWs reported that they were fully vaccinated and $21 \%$ had not been vaccinated at all [21].

In this study it was observed that only $34.62 \%$ of the HCWs were fully vaccinated with the 3 doses of Hepatitis B vaccination, while 7.69\% of the participants were incompletely vaccinated. Majority of the participants $(57.69 \%)$ were not vaccinated at all. These 
findings show that a major proportion of the $\mathrm{HCW}$ do not have a protective anti $\mathrm{HBs} \mathrm{Ab}$ levels and are susceptible to infection. An important observation was the participants who were incompletely vaccinated $(4 \%)$ with only two doses of Hepatitis B vaccination had not attained protective antibody levels of $>10$
$\mathrm{mIU} / \mathrm{ml}$ and a booster dose of Hepatitis B vaccination was recommended for these HCWs. Another important observation in our study was that $57.69 \%$ of our HCWs who had not received the vaccination were not immune and were still at a risk of Hepatitis B infection (Tables 2 and 3).

Table.1 Status of HBV vaccination of participants

\begin{tabular}{|l|l|l|}
\hline Vaccination status & Number & Percentage \\
\hline Complete vaccination & 18 & $34.62 \%$ \\
\hline Incomplete vaccination & 4 & $7.69 \%$ \\
\hline Not vaccinated & 30 & $57.69 \%$ \\
\hline Total & 52 & \\
\hline
\end{tabular}

Table.2 Anti-Hbs antibodies status of participants according to vaccination status $(\mathrm{n}=52)$

\begin{tabular}{|l|l|l|l|l|}
\hline Vaccination status & \multicolumn{2}{|l|}{$\begin{array}{l}\text { Anti-HBsAb titres (mIU/ml) <10 >10 \% of } \\
\text { participants with protective Anti-HBsAb levels }\end{array}$} & $\begin{array}{l}\text { P value } \\
\text { (chi-square) }\end{array}$ \\
\hline Complete Vaccination & 0 & 18 & $100 \%$ & 0.01 \\
\hline Incomplete vaccination & 4 & 0 & $0 \%$ & \\
\hline Not vaccinated & 30 & 0 & $0 \%$ & \\
\hline Total & 34 & 18 & $34.62 \%$ & \\
\hline
\end{tabular}

Fishers exact test should be used when any one cell less than 5. (Here one cell is 0 )

Table.3 Anti-HBs status of completely vaccinated participants in relation to time since vaccination $(\mathrm{n}=18)$

\begin{tabular}{|l|l|l|l|l|l|}
\hline $\begin{array}{c}\text { Vaccination time } \\
\text { (years elapsed) }\end{array}$ & $\begin{array}{c}\text { Anti HBs } \\
\text { titre } \\
<\mathbf{1 0 m I U / m l}\end{array}$ & $\begin{array}{c}\text { Anti HBs } \\
\text { titre 10-100 } \\
\mathbf{m I U} / \mathbf{m l}\end{array}$ & $\begin{array}{c}\text { Anti HBs } \\
\text { titre }>\mathbf{1 0 0} \\
\mathbf{m I U} / \mathbf{m l}\end{array}$ & $\begin{array}{l}\text { \% of subjects with } \\
\text { AntiHBs titre }>\mathbf{1 0 0} \\
\text { mIU/ml }\end{array}$ & $\begin{array}{l}\text { value } \\
\text { (chi square } \\
\text { test) }\end{array}$ \\
\hline$<5$ years $(\mathrm{N}=5)$ & 0 & 0 & 5 & $100 \%$ & 0.19 \\
\hline $5-10$ years $(\mathrm{N}=10)$ & 0 & 0 & 10 & $100 \%$ & \\
\hline$>10$ years $(\mathrm{N}=3)$ & 0 & 3 & 0 & $0 \%$ & \\
\hline Total & 0 & 3 & 15 & $83.33 \%$ & \\
\hline
\end{tabular}

Fishers' exact test is 0.19 .

\begin{tabular}{|l|l|l|l|l|}
\hline $\begin{array}{c}\text { Vaccination } \\
\text { time } \\
\text { (years elapsed) }\end{array}$ & $\begin{array}{c}\text { Anti HBs titre } \\
<10 \mathrm{mIU} / \mathrm{ml}\end{array}$ & $\begin{array}{c}\text { Anti HBs titre } \\
\mathbf{1 0 - 1 0 0} \mathrm{mIU} / \mathrm{ml}\end{array}$ & $\begin{array}{l}\text { Anti HBs titre } \\
>100 \mathrm{mIU} / \mathrm{ml}\end{array}$ & $\begin{array}{l}\text { P value } \\
\text { (Fishers exact } \\
\text { test) }\end{array}$ \\
\hline$<10$ years & 0 & 0 & 15 & $<0.001^{*}$ \\
\hline$>10$ years & 0 & 3 & 0 & \\
\hline Total & 0 & 3 & 15 & \\
\hline
\end{tabular}

*Fishers exact test 
It was observed that the 3 doctors who participated in the study had protective anti $\mathrm{HBsAb}$ levels. Of the 45 laboratory technicians, only $15(33.33 \%)$ of them had protective anti HBsAb levels, where has the remaining $30(66.67 \%)$ did not have protective anti HBsAb levels. Of the 4 laboratory attendants, none of them had protective anti HBsAb levels. This points to lack of awareness about the importance of Hepatitis B vaccination among the HCWs. This also shows negligence among the higher authorities for not implementing appropriate vaccination strategies and for not creating awareness among HCWs. The present study is similar to the studies conducted in Maulana Azad Medical College, New Delhi in which of the ones who received a complete course of HBV vaccination $73.5 \%$ showed protective levels [22].

This study brings forth the need for initiating awareness programmes and conducting awareness classes for all HCWs. It was surprising to notice that none of our laboratory attendants were aware for Hepatitis $\mathrm{B}$ infection and preventive measures. Hence our study highlights the importance of educating HCWs regarding using appropriate personal protective measures while handling blood and body fluids and also about the importance of documenting every needle stick injury. Awareness programmes should be conducted for all health care staff including doctors, nurses, house surgeons, medical and nursing students, laboratory technicians, laboratory attendants, grade IV staff.

The main reasons for non immunisation differ widely among the different cadres of health workers [23, 24]. The main causes of nonimmunisation among paramedical workers is due to lack of proper knowledge regarding occupation transmitted infections, lack of motivation, high cost of the vaccine and other causes $[23,24]$. A Taiwan study indicated that the concern about the efficacy of Hepatitis B vaccine, fear of pain from repeated injections, time and money were the main determinants among the nursing faculty for not having the immunisation for hepatitis B [25].

Every health care setting should introduce policies which would make it mandatory to check the Hepatitis B vaccination status for all the staff. For those who are found to be unvaccinated and for those who have low antibody titres there should be facilities to provide Hepatitis B vaccination free of cost. Records should be maintained regarding the Hepatitis B vaccination status of every health care staff \& the staff should be motivated to take the complete course of vaccination. In case of a needle stick injury or any exposure to blood or body fluids, there should also be facilities for documenting, counselling and post exposure management.

The risk of Hepatitis B infection is well documented among HCWs. Therefore there is a need to focus on implementing teaching programs to educate all the HCWs regarding the use of personal protective measures. Every health care institute should lay down clear policies for HBV screening, vaccination and for monitoring of serological response for all HCWs. All those who are found to have low antibody titres should be counselled and should be advised to take the complete course of vaccination. Antibody levels among those who are recently vaccinated should be checked after 1- 2 months after the last dose of vaccination and this should be recorded. The rate of anti-HBs decline is unpredictable, hence should be checked every 5 years.

\section{References}

1. European Association for the Study of the Liver. EASL clinical practice guidelines: Management of chronic hepatitis B virus infection. J Hepatol 2012;57:16785.

2. World Health Organization, Fact sheets. "Hepatitis B," 2014, http://www.who.int/mediacentre/factsheets/fs 
204/en/.

3. National Centre for Disease Control (NCDC). Quarterly Newsletter 2014; 3(1).

4. Jadeja P, Kaur A, Shekha H. Trend in seroprevalence of Hepatitis B virus infection among blood donors at a tertiary care centre of Rajasthan, India. National Journal of Medical Research 2014; 4:205-207.

5. Annapurna G.Sajjan, Smita S.Mangalgi. Awareness and ractice of complete hepatitis $B$ vaccination and anti-Hbs testing in vaccinated health care workers. JKIMCU, Vol.4, No.2, April-June 2015, 81 ISSN 22314261.

6. L. A. S. Ciorlia andD. M. T. Zanetta, "Hepatitis $\mathrm{B}$ in healthcare workers: prevalence, vaccination and relation to occupational factors," Brazilian Journal of Infectious Diseases, vol. 9, no. 5, pp. 384-389, 2005.

7. E. Dannetun, A. Tegnell, A. Torner, and J. Giesecke, "Coverage of hepatitis B vaccination in Swedish healthcare workers," Journal of Hospital Infection, vol. 63, no. 2, pp. 201-204, 2006.

8. EPINET, "Needle stick prevention devices," Health Devices, vol. 28, pp. 381-407, 1999.

9. European Consensus Group on Hepatitis B Immunity, "Are booster immunizations needed for lifelong hepatitis B immunity?" The Lancet, vol. 355, pp. 561-565, 2000.

10. Screening for hepatitis $B$ and $C$ viral markers among nursing students in a tertiary care hospital Indian Journal of Medical Microbiology, Vol. 28, No. 1, JanuaryMarch, 2010, pp. 78-79.

11.Yen $\mathrm{YH}$, Chen $\mathrm{CH}$, Wang $\mathrm{JH}$, Lee $\mathrm{CM}$, Changchien CS, Lu SN. (2005) Liver Int. 25: 1162-1168.

12. Alvardo-Ramy F, Beltrami EM. (2003) Cleve Clin J Med. 70: 457-465.

13. Banatvala J, van Damme P, Oehen S. (2000) Vaccine. 19: 877-885.

14. Chathuranga LS, Noordeen F, Abeykoon
AMSB. (2013) Int. J. Infect. Dis. 17: 10781079.

15. Eltayib HAA. (2014) Int. J. Med. Hlth. Sci. Res. 1: 29-36.

16Sukriti, Pati NT, Sethi A, et al. Low level of awareness, vaccine coverage, and the need for booster among health care workers in tertiary care hospitals in India. $J$ Gastroenterol Hepatol 2008;23:1710-1715.

17.Duseja A, Arora L, Masih B, et al. Hepatitis B and $\mathrm{C}$ Virus- prevalence and prevention in health care workers. Trop Gastroenterol 2002;23:125-126.

18.Shrestha SK, Bhattarai MD. Study of hepatitis B among different categories of health care workers. J Coll Physicians Surg Pak 2006;16:108-111.

19.Taalal M, Kandeel A, El-shoubary W, et al. Occupational exposure to needle stick injuries and hepatitis vaccine coverage among healthcare workers in Egypt. Am J Infect Control 2003;31:469-474.

20. Prüss-Üstün A, Rapiti E, Hutin Y (2005) Estimation of the global burden of disease from sharps injuries to health-care workers. Am J Ind Med 48: 482-490.

21. G. Singh, M. P. Singh, I. Walia, C. Sarin, and R. K. Ratho, "Screening for hepatitis B and C viral markers among nursing students in a tertiary care hospital," Indian Journal of Medical Microbiology, vol. 28, no. 1, pp. 7879, 2010.

22. Arun Kumar Jha et al, "Hepatitis B infection in microbiology laboratory workers: prevalence, vaccination and immunity status," Hepatitis research and treatment, vol 2012, article id 520362.

23. Poland GA. (1998) Am. J. Prev. Med. 15: 7377.

24. CDC. (2001) MMWR. 50: 1-42.

25. Kermode M, Jolley D, Langkham B, Thomas M, Crofts N. (2005) Am. J. Infect. Contr. 33: 34-41.

\section{How to cite this article:}

Reshmi Gopalakrishnan and Srinath Ramamurthy. 2017. Seroprevalence of Hepatitis B Infection among Health Care Workers and the Importance of Anti HBs Testing among the Health Care Workers. Int.J.Curr.Microbiol.App.Sci. 6(10): 2280-2285.

doi: $\underline{\text { https://doi.org/10.20546/ijcmas.2017.610.270 }}$ 